\title{
KARYA SENI GLASS PAINTING SEBAGAI OBJEK PENGEMBANGAN PEMBELAJARAN SENI RUPA DAN KETERAMPILAN DI SMPN 1 DAN SMPN 2 KOTA PADANG
}

\author{
Lisa Widiarti ${ }^{1 *}$, Eliya Pebriyeni ${ }^{2 *}$ \\ Program Studi Pendidikan Seni Rupa Jurusan Seni Rupa Fakultas Bahasa dan Seni \\ Universitas Negeri Padang \\ Jl. Prof. Dr. Hamta, Air Tawar Padang, Kel. Air Tawar Barat, Kec. Padang Utara, Kota Padang, Kode Pos 25171 \\ Sumatera Barat. Indonesia \\ Email: lisa.widiarti@yahoo.co.id
}

\begin{abstract}
Abstrak
Pelaksanaan pendidikan seni rupa di sekolah umum terutama tingkat pendidikan lanjutan harus berdasarkan prinsip bahwa pendidikan seni merupakan wahana bermuatan edukatif dan membangun kreativitas siswa. Orientasi mata pelajaran Seni budaya/Seni Rupa di SMP adalah memfasilitasi pengalaman emosi, intelektual, fisik, konsepsi, sosial, estetis, artistik dan kreativitas kepada siswa dengan melakukan aktivitas apreasiasi dan kreasi terhadap berbagai produk benda di sekitar siswa yang bermanfaat bagi kehidupan manusia. Pemilihan media yang tepat dalam berkarya seni bagi siswa merupakan hal yang tepat untuk terciptanya hasil karya yang kreatif dan juga akan membuat siswa lebih tertarik dalam pembelajaran dan akan berlangsung dengan menyenangkan. Namun dalam pelaksanaannya, mata pelajaran Seni Budaya seringkali digantikan dengan mata pelajaran lain dikarenakan banyak guru yang tidak menguasai materi pembelajaran Seni Budaya tersebut. Kenyataan di lapangan, khususnya pembelajaran dalam bidang Seni rupa dan keterampilan dihadapkan dengan berbagai permasalahan, diantaranya kualitas keahlian tenaga pengajar serta waktu pembelajaran pada setiap pertemuan di kelas yang sangat singkat. Hal ini menjadikan guru sulit menyelesaikan materi yang digariskan oleh GBPP; dan akhirnya mengakibatkan masalah materi pembelajaran menjadi rancu karena sering berubah-ubah. PKM ini difokuskan kepada aspek pelatihan terhadap guru dalam mengatasi masalah penguasaan materi dan alternatif bahan yang dapat dimanfaatkan untuk praktikum pada pembelajaran Seni Rupa. Salah satu upaya dalam pengembangan media berkarya yang menyenangkan bagi siswa yaitu membuat karya seni glass painting, dengan menggunakan media kaca, gelas atau memanfaatkan botol-botol kaca bekas. Dalam hal ini para guru akan diajarkan bagaimana memanfaatkan bahan bekas seperti kaca atau botol-botol kaca, untuk membuat karya seni murni atau terapan yang relatif mudah untuk diajarkan kepada murid SMP serta relatif membutuhkan waktu yang cukup singkat. Penentuan masalah prioritas dilakukan bersama antara Tim Pelaksana dengan Pimpinan Mitra. Pemecahan masalah dilakukan dengan metode: (1) ceramah, (2) demonstrasi/peragaan, dan (3) pelatihan dengan bimbingan para instruktur dan diakhiri dengan tanya jawab. Rencana target luaran kegiatan adalah: (1) mempublikasikan artikel pelatihan (2) peningkatan pemahaman guru mitra tentang pengertian, teknik dan proses yang cukup sederhana dalam memanfaatkan media kaca, dan (3) menghasilkan produk / karya: minimal setiap peserta menghasilkan dua karya seni glass painting, berupa satu karya seni murni dan satu lagi karya seni terapan.
\end{abstract}

Kata Kunci: karya seni glass painting, proses, teknik..

\begin{abstract}
The implementation of fine arts education in public schools, especially the level of further education, must be based on the principle that art education is an educationally charged vehicle and builds students' creativity. The subject orientation of Cultural / Fine Arts in Middle School is facilitating emotional, intellectual, physical, conception, social, aesthetic, artistic and creativity experiences to students by carrying out activities of appreciation and creation of various objects products around students that benefit human life. Choosing the right media in creating art for students is the right thing to create creative work and will also make students more interested in learning and will take place pleasantly. But in its implementation, Cultural Arts subjects are often replaced with other subjects because many teachers do not master the Cultural Arts learning material. Reality in the field, especially learning in the field of Fine Arts and skills are faced with various problems, including the quality of the teaching staff's expertise and the learning time at each meeting in a very short class. This makes it difficult for teachers to complete the material outlined by GBPP; and finally resulting in the problem of
\end{abstract}




\section{Gorga Jurnal Seni Rupa \\ Volume 08 Nomor 01 \\ p-ISSN: 2301-5942 | e-ISSN: 2580-2380}

learning material becoming ambiguous because it often changes. This PKM is focused on aspects of training of teachers in overcoming the problem of mastering the material and alternative materials that can be used for practicum in the learning of Fine Arts. One effort in developing creative media is fun for students, namely making glass painting artworks, using glass media, glass or using used glass bottles. In this case the teachers will be taught how to use used materials such as glass or glass bottles, to make pure or applied works of art that are relatively easy to teach to middle school students and relatively require a relatively short amount of time. Determination of priority issues is carried out jointly between the Implementation Team and the Partner Leaders. Problem solving is done by methods: (1) lectures, (2) demonstrations / demonstrations, and (3) training with the guidance of instructors and ending with questions and answers. The activity target plan is: (1) publishing training articles (2) improving the understanding of partner teachers about understanding, techniques and processes that are quite simple in using glass media, and (3) producing products / works: at least each participant produces two glass artworks painting, in the form of one pure art work and one applied art work.

Keywords: glass painting, process, technique, artwork.

\section{PENDAHULUAN}

Mata Pelajaran Seni Rupa, terutama di Sekolah Menengah Pertama (SMP), pada dasarnya untuk meningkatkan cita rasa keindahan, menumbuhkan kepekaan rasa keindahan dan meningkatkan daya cipta seni. Hal ini dapat tumbuh dan berkembang dengan serangkaian pembelajaran, pengamatan, penilaian, penghargaan terhadap karya seni. Mulyasa, E. (2010) " Standar Kompetensi Kelompok Mata Pelajaran Estetika untuk SMP adalah: (1). Memanfaatkan lingkungan untuk kegiatan apresiasi seni. (2). Menghargai karya seni, budaya dan ketrampilan sesuai dengan kekhasan lokal. (3). Menunjukkan kegemaran membaca dan menulis karya seni”. (hlm. 107) Adapun tujuan pembelajaran seni adalah " Memahami arti seni, mengembangkan kepekaan terhadap seni, mengembangkan estetika, mengembangkan kemampuan berapresiasi, berkarya kreatif". (Pendidikan Nasional, 1993-1994: 87).

Selanjutnya Depdiknas (2003) menjelaskan, Peranan Seni Budaya dan Keterampilan membentuk kepribadian siswa secara menyeluruh, harmonis mencakup logika, kinestetika, estetis dan artistik dalam pengembangan kreativitas, kepekaan rasa dan indera, serta beretika. Seni Budaya dan Keterampilan memenuhi kebutuhan perkembangan siswa dalam mencapai kecerdasan emosional (EQ), kecerdasan intelektual (IQ), kecerdasan adversitas (AQ), dan kreativitas (CQ), serta kecerdasan spiritual dan moral (SQ). Seni Budaya dan Keterampilan bagi siswa memiliki kekhasan berdasarkan kaidah keilmuan masing-masing dan disusun sesuai dengan kebutuhan siswa mencakup: unsur-unsur, prinsipprinsip, proses dan teknik berkarya, nilai budaya dan tidak mengesampingkan aspek fungsi, serta sesuai dengan konteks sosial budaya masyarakat, menumbuhkan sikap saling memahami, menghargai, dan saling menghormati.

Kegiatan pembelajaran mata pelajaran Seni Rupa dan Keterampilan sering diabaikan dan diganti dengan mata pelajaran lain dikarena sebagian besar guruguru merasa tidak memiliki kemampuan yang memadai untuk mengajarkan materi- materi tersebut. Mereka merasa tidak berbakat, oleh karena menurut anggapan mereka, guru yang mengajar pendidikan seni harus memiliki bakat.

PKM ini difokuskan kepada aspek permasalahan pada materi pembelajaran seni rupa dan keterampilan, yaitu pada aspek penguasaan materi pembelajaran. Untuk mengatasi masalah, diberikan materi pembelajaran yang tidak terlalu sulit bagi guru dan juga mudah untuk diajarkan dan dikerjakan murid tingkat SMP. Dalam pelatihan diajarkan proses dan cara membuat karya seni kerajinan glass painting, yang dalam pelaksanaannya murid-murid bisa belajar sambil bermain dengan sangat menyenangkan.

Dalam kegiatan PKM ini, materi glass painting yang akan dilatihkan adalah dengan memanfaatkan bahan limbah kaca seperti botol-botol kaca bekas yang gampang didapatkan di sekitar lingkungan tempat tinggal. Pelatihan ini memiliki keuntungan ganda, karena di samping membina dan memupuk sikap berkesenian, juga ramah lingkungan. Hal tersebut disebabkan karena bahan yang digunakan bisa dengan memanfaatkan sesuatu yang banyak terdapat disekeliling tempat tinggal. Hal ini mengurangi kecenderungan yang selama ini terjadi di sekolah, yaitu bahan-bahan praktikum pembelajaran selalu didapatkan dengan membeli, padahal di sekitar kita banyak ditemukan bahan-bahan limbah yang dapat dijadikan sebagai media ekspresi yang bernilai seni. 


\section{Gorga Jurnal Seni Rupa \\ Volume 08 Nomor 01 \\ p-ISSN: 2301-5942 | e-ISSN: 2580-2380}

Materi pembelajaran pelatihan ini juga membantu kebingungan guru dalam mencari alternatif media yang bisa digunakan pada pelajaran seni rupa dan keterampilan. Di samping itu, bagi murid tugas praktikum seni rupa dan keterampilan ini juga dapat diselesaikan di sekolah dalam batas waktu pembelajaran yang relatif singkat tanpa harus dibawa pulang ke rumah, sehingga menghindari kemungkinan untuk dikerjakan oleh orang lain selain oleh murid itu sendiri. Permasalahan yang dipecahkan disesuaikan dengan keahlian tim pelaksana yaitu masalah yang menghambat ketuntasan pelaksanaan kurikulum dan berhubungan langsung dengan guru dalam kegiatan pembelajaran.

Berdasarkan gambaran analisis situasi, ditemukan berbagai masalah yang dihadapi oleh guru SMP Mitra. Dari sekian banyak masalah tersebut, ditetapkan masalah prioritas yang akan diselesaikan dalam Program PKM ini. Penetapan masalah prioritas dilakukan secara bersama antara Tim Pelaksana dengan mitra yang diwakili oleh Kepala SMP Mitra. Pemecahan masalah difokuskan pada pembelajaran seni rupa aspek penguasaan materi pembelajaran keterampilan, yaitu: belum dapat memahami banyaknya alternatif yang dapat dimanfaatkan sebagai media praktikum dalam mata pelajaran Seni Budaya dan Keterampilan, sehingga dalam pelaksanaan pembelajaran, materi ini sering ditinggalkan, belum dapat menerapkan proses dan teknik yang tepat ke dalam bentuk tugas yang akan dikerjakan siswa, dan belum dapat mengaplikasikan alternatif bahan-bahan praktikum berupa bendabenda yang ada di sekeliling kita sebagai bahan praktikum keterampilan yang akan dikerjakan murid.

\section{KAJIAN TEORI}

Lukisan kaca merupakan salah satu keterampilan dalam cabang seni lukis dengan menggunakan media kaca, dimana teknik melukisnya adalah terbalik atau melukis dibagian belakang dan menikmati hasilnya dari bagian depan.

Keterampilan dalam melukis kaca ini mempunyai nilai seni yang khas dengan aneka ragam paduan warna yang sangat menarik. kerajinan ini berbeda dengan kaca-kaca dekorasi yang biasanya bisa dijumpai di toko-toko souvenir atau toko kerajinan. Produk lukisan kaca sering disebut juga sebagai decorative glass painting bisa diterapkan pada kaca, gelas, toples, botol-botol bekas, bola lampu, dll.

Adapun Alat-alat dan bahan yang dibutuh untuk membuat karya seni lukisan kaca ini adalah : kuas, cat, pola/gambar, yang bisa di terapkan pada media yang akan dilukis seperti : kaca, gelas, toples, botol, dll.

Untuk pemula sebaiknya memakai kaca yang datar tanpa lengkungan-lengkungan. Siapkan gambarnya lalu tempel dibelakang kaca atau dibagian dalam kaca. Gambar/motif di belakang kaca mempermudah proses mengecat karena kita tinggal mengikuti motif atau pola gambar tsb. Tapi sebelum di cat atau digambar kaca harus dibersihkan dari minyak atau kotoran yang menempel lalu di keringkan. Cat yang dipakai juga harus diaduk sampai tercampur rata agar hasil cat di kaca benar-benar sempurna. Setelah kaca dicat dibiarkan kering atau dijemur dengan matahari, kalau di jemur di matahari usahakan jangan terkena debu, atau bisa juga dikeringkan dengan hairdryer.

Adapun keunggulan karya seni kerajinan lukis kaca ini adalah:

1) Membuatnya sangat mudah dan bisa dilakukan oleh segala usia.

2) Bahan-bahan dari bahan kaca bekas gampang didapatkan, seperti; gelas, toples, botol namun hasilnya mampu menciptakan benda-benda dengan nilai seni tinggi.

3) Dengan menguasai kemampuan membuat karya seni kerajinan lukis kaca ini, kedepannya dapat membuka peluang bisnis.

\section{Persiapan Peralatan}

Untuk memperlancar proses berkarya, sebaiknya sebelum memulai membuat karya terlebih dulu kita mempersiapkan semua peralatan dan bahan yang dibutuhkan ketika bekerja, seperti kuas, cat, palet cat, gunting, cutter, selotip, kapas, dan lainnya.

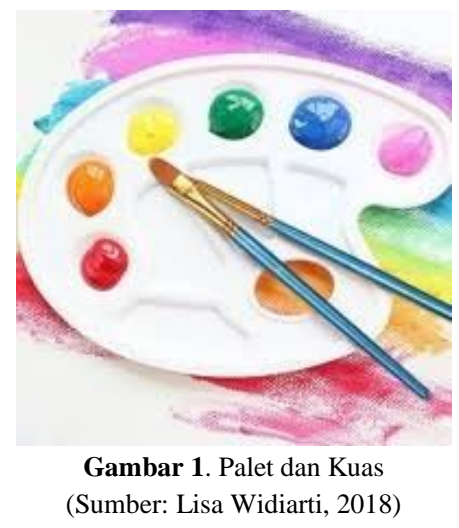



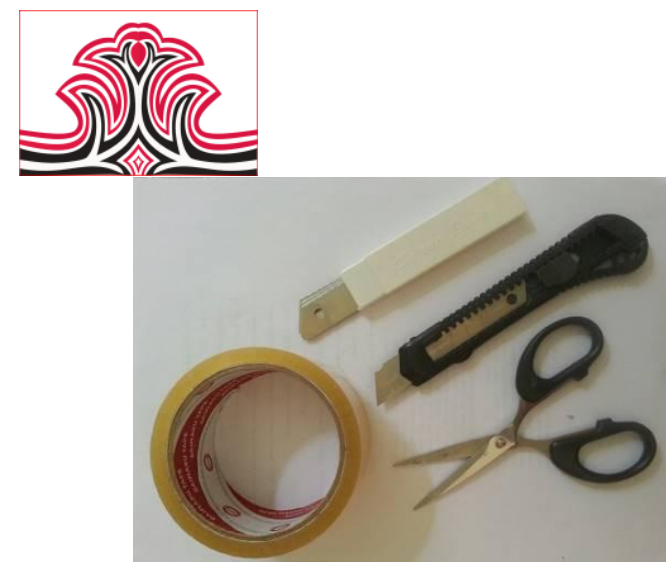

Gambar 2. Alat yang Digunakan

(Sumber: Lisa Widiarti, 2018)

\section{2).Pemilihan Material}

Kita dapat menggunakan benda benda yang terbuat dari kaca disekitar rumah kita misalnya: kaca datar, Gelas, piring, stoples, botol bumbu, botol minuman, tempat selai, dll. Pilihlah yang bentuknya menarik \& artistik. Pilihlah permukaan kaca yang masih bagus, benda atau kaca yang sudah banyak goresannya atau buram sebaiknya jangan dipakai, karena akan mengurangi keindahan.

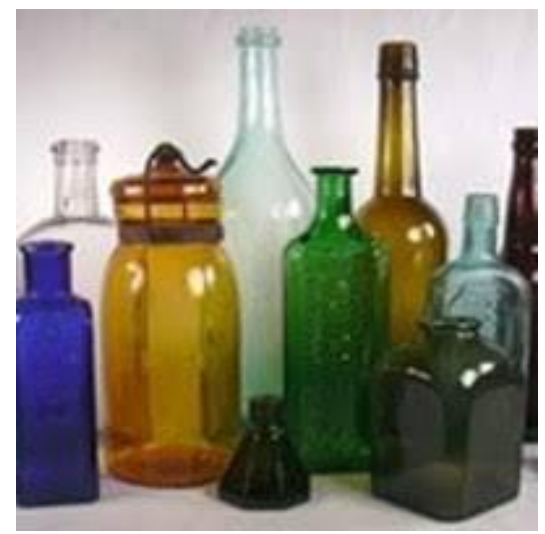

Gambar 3. Glass Painting (Sumber: Lisa Widiarti, 2018)
Gorga Jurnal Seni Rupa

Volume 08 Nomor 0 p-ISSN: 2301-5942 | e-ISSN: 2580-2380

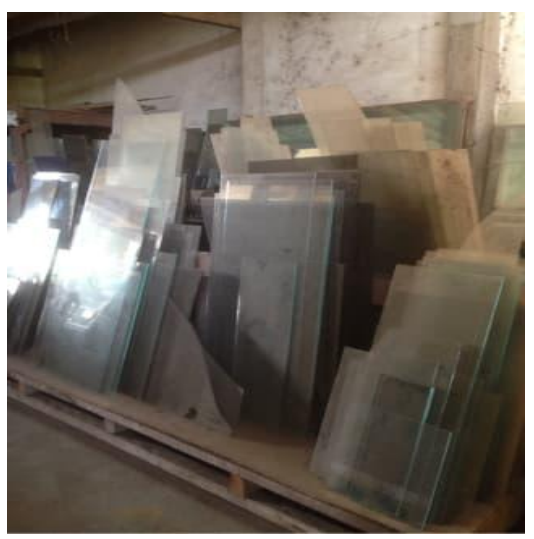

Gambar 4. Kaca

(Sumber: Lisa Widiarti, 2018)

\section{3).Teknik Membersihkan Media Kaca}

Glass (kaca) yang akan kita lukis sebaiknya kita bersihkan dulu, bisa dengan menggunakan sabun cuci piring, untuk membersihkan kotoran yang menempel terutama lemak/minyak. Sebelum permukaan kaca dilukis, sebaiknya dilap dengan kain bersih/tissue dengan menggunakan methanol (spiritus). Teknik membersihkan yang benar akan menghasilkan hasil lukisan yang bagus \& bisa menempel lebih kuat.

\section{4).Pembuatan Pola Lukisan}

Buatlah garis besar pola gambar pada kaca dengan spidol permanen. Saat melakukan semua ini, berhatihatilah agar pola tidak rusak. Namun, jika hal itu terjadi, usap bagian yang ternoda dengan kapas atau sepotong kain yang telah dicelupkan ke remover cat kuku. Untuk membuat pola lukisan, motif yang akan dilukis bisa bermacam macam, tergantung selera. Umumnya motif yang cukup mudah \& sederhana untuk pemula bisa berupa aneka bunga, kupu-kupu, capung, nuansa laut, kartun, ataupun gambar aneka binatang. kita bisa langsung memindahkan pola gambar yang akan dilukis dengan menggunakan spidol permanen.

Untuk pemula bisa juga membuat/meniru pola gambar yang sudah ada pada kertas dengan cara menjiplak dengan menempelkan gambar yang akan dijiplak tersebut di sisi dalam kaca. Selanjutnya barulah hasil jiplakan pola gambar tersebut di cat. 


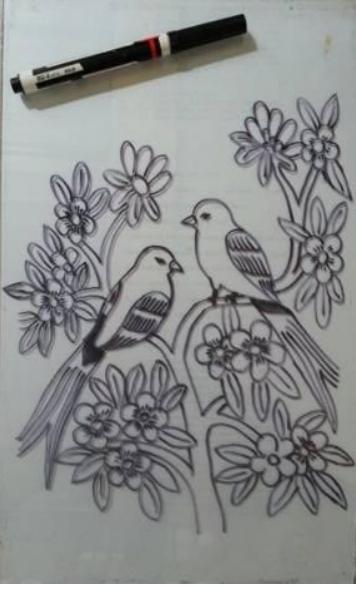

Gambar 5. Sket Burung (Sumber: Lisa Widiarti, 2018)

\section{5).Pemilihan Cat}

\section{(1).Cat Opaque Coates}

Jenis Cat Opaque Coates sifatnya menutupi permukaan / tidak transparant. Cat ini harganya cukup ekonomis, sehingga cocok untuk pemula yang baru berlatih membuat karya Glass Painting. Sebelum diaplikasikan, cat di encerkan dulu dengan Thinner \& ditambah Glass Fixed Catalist $( \pm 5 \%)$.

\section{(2).Cat Transparent Vetro}

Jenis cat Transparent Vetro ini bersifat Transparan \& Exclusive, sangat indah hasilnya karena menghasilkan warna warna yang cerah \& transparan. Harganya cukup Mahal. Untuk Aplikasinya bisa langsung dikuaskan pada media kaca yang sudah dibersihkan. Apabila Terlalu kental/sudah mengental bisa dicairkan dengan Thinner. Cat ini digunakan apabila kita sudah mengerti teknik Glass Painting atau sudah berlatih dengan menggunakan Cat Opaque Coates.

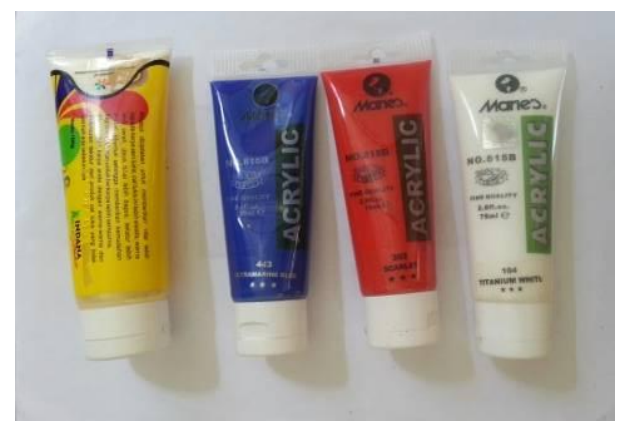

\section{6).Proses Pengecatan}

Biarkan gambar pola mengering sejenak, dan kemudian dilanjutkan dengan mengisi bidang gambar yang telah di buat di permukaan kaca tersebut. Pengecatan dilakukan secara bertahap dengan Cat Opaque Coates, Cat Transparent Vetro, cat acrylic atau cat yang sesuai dengan keinginan kita. Usahakan untuk tidak memegang kaca yang di lukis secara vertikal untuk menghindari warna yang di kuas kan jadi menetes. Gambar yang di Cat sebaiknya jangan terlalu tebal, agar hasilnya rata. Setelah dicat, usahakan tidak tersentuh tangan sebelum catnya kering. Jika ada gelembung cat yang terjadi ketika cat di kuas kan, tusuk gelembung tersebut dengan jarum atau peniti agar kembali datar dan hindari menerapkan dua lapis cat dalam setiap bagian pola.

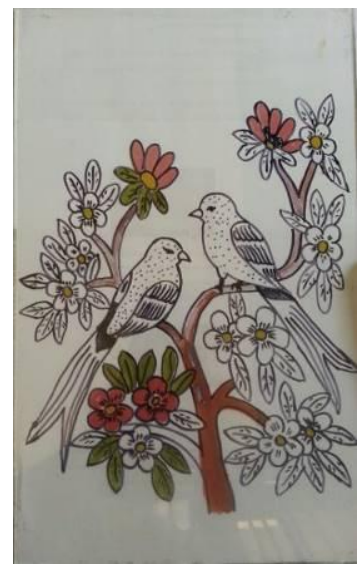

Gambar 7. Proses Pengecatan (Sumber: Lisa Widiarti, 2018)

\section{7).Proses Akhir (Finishing)}

Setelah proses pengecatan selesai, agar cat bisa lebih fix menempel dikaca, bisa di oven dengan panas 120 Celcius - 160 Celcius selama 15 - 40 menit atau cara yang paling sederhana bisa dengan menjemur karya dibawah terik matahari. 


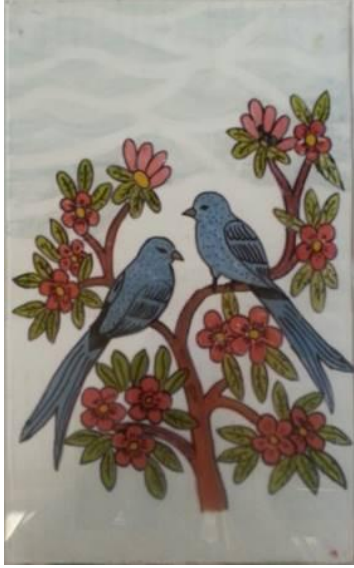

Gambar 8. Finishing

(Sumber: Lisa Widiarti, 2018)

\section{METODE PENELITIAN}

Metode yang ditawarkan untuk memecahkan masalah adalah dengan melaksanakan pelatihan secara menyeluruh, baik teori maupun praktik, serta pengadaan bahan dan alat praktikum. Agar tujuan dapat dicapai secara maksimal, maka metode pendekatan dilakukan secara bertahap, yaitu: (1) Persiapan pelaksanaan teknis administratif, (2) Pelaksanaan kegiatan, (3) Pelaporan hasil. Rincian tahapan kegiatan adalah sebagai berikut:

\section{Persiapan Teknis Administratif}

Seluruh kegiatan persiapan teknis administratif dilakukan atas kerjasama Tim Pelaksana dengan Kepala SMP Mitra. Rekrutmen dan seleksi peserta juga dilakukan atas kerjasama Tim Pelaksana dengan Kepala sekolah mitra yaitu Kepala SMP Negeri 1 dan Kepala SMP Negeri 2 Padang. Total para peserta yang ikut dalam pelatihan ini adalah 10 orang guru Seni Budaya dan Keterampilan, 5 orang guru SMP 1 dan 5 orang guru SMP 2 Padang serta 2 orang kepala sekolah.

\section{Penyuluhan}

Penyuluhan dilakukan agar khalayak sasaran memahami materi pelatihan sebelum mengaplikasikannya. Materi penyuluhan adalah: Pengertian proses, teknik dan bahan dalam berkarya dan Pengertian dan proses pembuatan disain / gambar.

\section{Pelatihan dan Pameran}

Pelatihan dilakukan dengan melaksanakan praktikum terbimbing, sehingga setiap hambatan pelatihan disaat praktikum bisa segera diselesaikan. Materi yang dilatihkan adalah: membuat karya keterampilan dengan media kaca dan setiap peserta menghasilkan beberapa karya dengan disain dan media ungkap yang berbeda. Pameran karya sebagai bentuk salah satu penghargaan terhadap hasil karya peserta.

\section{Persiapan Kegiatan}

Mempersiapkan semua keperluan pelatihan untuk setiap peserta berupa; makalah, peralatan administrasi untuk keperluan pencatatan, bahan dan alat praktikum untuk mengaplikasikan pengetahuan yang dimiliki dalam bentuk karya. Penyajian materi dalam bentuk penyuluhan untuk meningkatkan pemahaman peserta pelatihan terhadap materi PKM ini. Memperbanyak makalah materi pelatihan (teori)

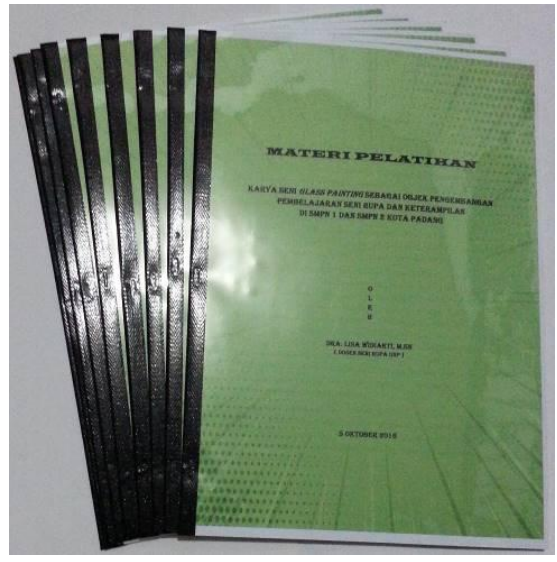

Gambar 9. Makalah Pelatihan (Sumber: Lisa Widiarti, 2018)

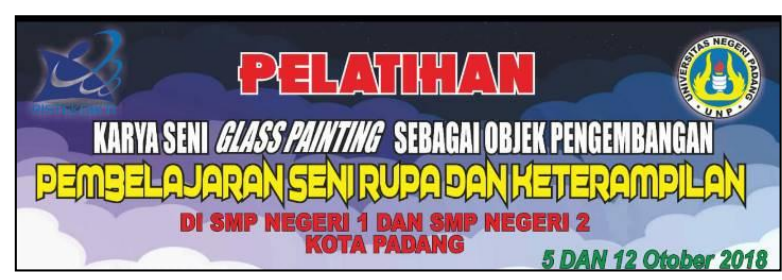

Gambar 10. Spanduk Pelatihan (Sumber: Lisa Widiarti, 2018)

Untuk memperlancar proses berkarya, sebaiknya sebelum memulai membuat karya terlebih dulu kita mempersiapkan semua peralatan dan bahan yang dibutuhkan ketika bekerja, seperti kuas, cat lukis, palet lukis, gunting, cutter, selotip, kapas, dan lainnya.

\section{Pelaksanaan Pelatihan}

Membagikan makalah dan berbagai keperluan pelatihan kepada peserta pelatihan. Penyajian materi untuk pemahaman pengertian, teknik dan proses pengerjaan karya keterampilan dengan media kaca dalam wujud karya seni kerajinan Lukis Kaca. 

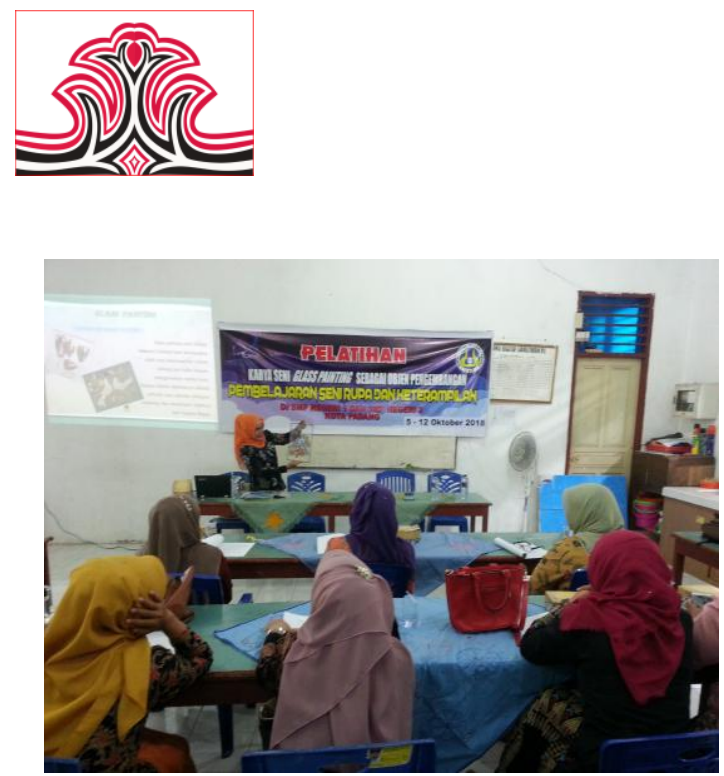

Gambar 11. Suasana Pelatihan Materi Teori (Sumber: Lisa Widiarti, 2018)

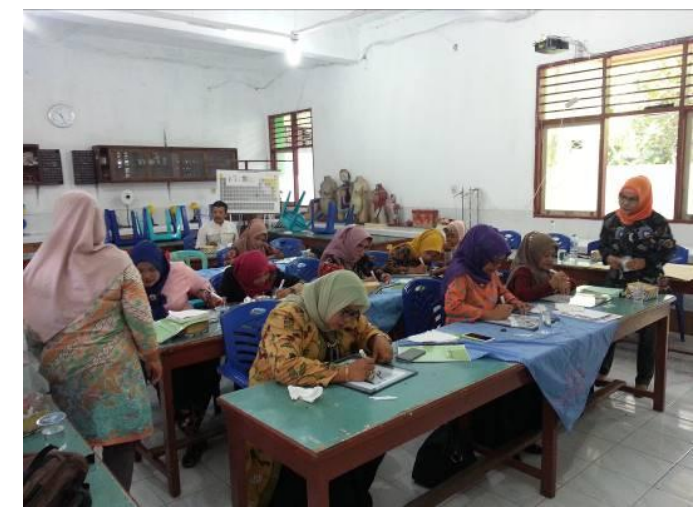

Gambar 12. Suasana Pelatihan Peserta Serius dalam Mengikuti Pelatihan

(Sumber: Lisa Widiarti, 2018)

\section{Penilaian}

Penilaian awal untuk mengukur kemampuan awal calon peserta melalui tanya jawab dan diskusi tentang materi Glass painting sebelum pelatihan dilaksanakan. Penilaian proses untuk mengukur kemampuan peserta pada setiap tahap disaat kegiatan pelatihan sedang berlangsung, yang berguna untuk menyempurnakan kegiatan selanjutnya. Penilaian akhir berdasarkan hasil pelatihan, yang berguna untuk mengukur ketercapaian tujuan program kegiatan.

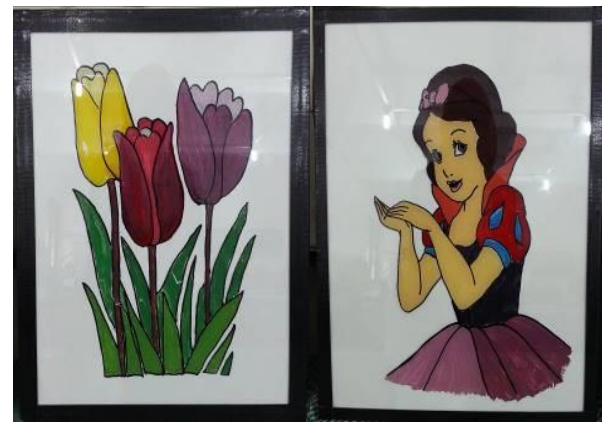

Gorga Jurnal Seni Rupa

Volume 08 Nomor 01

p-ISSN: 2301-5942 | e-ISSN: 2580-2380

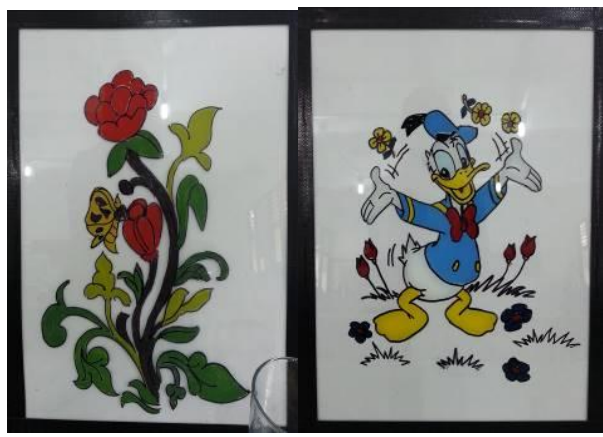

Gambar 13. Hasil Karya Pelatihan Praktek (Sumber: Lisa Widiarti, 2018)

\section{HASIL DAN PEMBAHASAN}

Dari 10 orang peserta pelatihan, hanya satu orang guru yang mengajar Seni Budaya yang mempunyai latar belakang pendidikan Seni Rupa sehingga bisa dikatakan $90 \%$ peserta pelatihan belum dapat memahami secara baik tentang pengertian, konsep, bahan, dan proses pembuatan karya seni rupa dan keterampilan dengan mempergunakan media kaca atau pun botol-botol bekas sebagai bahan pembuatan karya praktikum. Pada akhir kegiatan, para Guru SMPN Mitra telah memperlihatkan hasil pemahaman baik secara teori maupun penguasaan secara praktek tentang materi pelatihanyang diberikan. Hal ini bisa diketahui dari hasil dan dialog secara lisan disaat pelaksanaan praktikum sedang berlangsung.

Adapun karya glass painting yang dihasilkan terdiri dari tiga jenis media ungkap yaitu kaca datar, gelas, serta botol. Ketiga produk ini diolah dengan menggunakan teknik lukis menggunakan cat akrilik. Selama kegiatan penyajian materi, peserta terlihat antusias mengikuti kegiatan. Mencatat materi penting yang disajikan serta aktif melakukan tanya jawab.

Target luaran kegiatan yang ditetapkan dalam kegiatan pelatihan ini adalah peserta menghasilkan karya keterampilan dengan menggunakan media kaca seperti kaca datar, gelas, ataupun stoples dan botolbotol bekas sebagai bahan pembuatan karya seni dan keterampilan. Peserta dilatih untuk mampu berkreasi dalam mengolah media kaca sebagai bahan dasar berkarya menjadi benda seni. Artinya, setiap peserta dalam pelatihan tersebut memiliki keterampilan dan pengetahuan didalam mengolah bahan yang mudah didapatkan yang sebagian besar merupakan bahan terbuang. Dengan demikian maka target luaran yang ditetapkan dapat dicapai dengan baik. Disesuaikan dengan dua aspek permasalahan dan target luaran pada setiap aspek permasalahan. Manajemen bahan praktikum pembelajaran seni rupa dan keterampilan. Guru SMPN Mitra telah dapat mengidentifikasi dan 


\author{
Gorga Jurnal Seni Rupa \\ Volume 08 Nomor 01 \\ p-ISSN: 2301-5942 | e-ISSN: 2580-2380
}

mengelola botol-botol bekas yang ada di lingkungan sekitar tempat tinggal murid dapat dijadikan sebagai bahan praktikum pembelajaran Seni Rupa dan Keterampilan. Sesuai dengan target luaran: telah dihasilkan produk media pelatihan dengan spesifikasi media pelatihan bahan praktikum dari bahan-bahan yang ada di lingkungan murid. Bahan tersebut diantaranya adalah botol-botol bekas yang terbuat dari kaca.

Dari berbagai jenis media kaca tersebut, Guru SMPN Mitra bisa memilih dan mempersiapkan botol-botol bekas yang ada di lingkungan murid sebagai bahan praktikum sesuai dengan tujuan pembelajaran yang akan dicapai. Pada kegiatan pelatihan, Guru SMPN Mitra memilih botol bekas yang terbuat dari kaca untuk membuat karya seni rupa dan keterampilan. Pemilihan bahan praktikum dari botol-botol bekas ini telah membuka wawasan guru SDN Mitra, bahwa untuk pembelajaran Seni Budaya dan Prakarya tidak harus mengadakan bahan dengan cara membeli, tetapi bisa dengan cara memanfaatkan bahan-bahan limbah yang ada di lingkungan tempat tinggal siswa sebagai bahan praktikum pembuatan karya.

Adanya peningkatan pemahaman Guru SMPN Mitra dalam menguasai materi dan bahan praktikum. Pada awal kegiatan sangat sedikit sekali para guru peserta pelatihan tersebut yang memiliki pengetahuan tentang bahan yang bisa dipakai untuk berkarya. Namun pada akhir kegiatan, para guru peserta pelatihan itu telah memahami dan mengetahui bahwa sesungguhnya sangat banyak bahan yang bisa dimanfaatkan sebagai media dalam membuat karya seni rupa dan keterampilan tanpa harus membelinya.

Minimal setiap peserta menghasilkan tiga karya seni rupa dan keterampilan dari bahan-bahan kaca. Hasil yang didapatkan dari pelatihan ini dijadikan sebagai media pembelajaran/pelatihan untuk memperlancar interaksi komunikasi selama kegiatan penyampaian informasi pelatihan.

\section{KESIMPULAN DAN SARAN}

Berdasarkan hasil pelaksanaan kegiatan Pengabdian kepada Masyarakat ini dan uraian pembahasan di atas, dapat disimpulkan serta saran beberapa hal sebagai berikut ini:

Pelatihan ini memberikan beberapa materi yang terkait dengan upaya menambah pengetahuandan wawasan guru (para peserta pelatihan) tentang karya ketrampilan dengan memanfaatkanbahanbubur kertasmenjadi karya keterampilan yang bermanfaat untuk diajarkan pada murid-murid SD. Peserta menyambut positif kegiatan ini dan materi yang disajikan dapat dipahami oleh para peserta. Kegiatan berlangsung lancar, tepat waktu dan sesuai dengan yang diharapkan serta para peserta dapat berkomunikasi dengan para instruktur dan peserta lain dengan baik. Program pelatihan ini sangat bermanfaat dalam upaya meningkatkan kemampuan dan kreativitas para guru dalam bidang seni dan keterampilan khususnya guru seni budaya, sehingga hendaknya program pelatihan sejenis sering diselenggarakan. Hendaknya program ini dapat terus berlanjut sehingga lebih banyak lagi guru-guru seni budaya dari sekolah lainnya yang dapat merasakan manfaatnya. Para peserta pelatihan diharapkan dapat ikut aktif berperan dalam mengembangkan kreativitas pemanfaatan bahan bekas kaca menjadi karya keterampilan yang dapat diajarkan kepada muridmurid.

\section{DAFTAR RUJUKAN}

Direktorat Riset dan Pengabdian kepada Masyarakat.2017. Panduan Pelaksanaan Penelitian dan Pengabdian kepada Masyarakat di Perguruan Tinggi Edisi XI Tahun 2017. Jakarta: Direktorat Riset dan Pengabdian kepada Masyarakat, Direktorat Jenderal Penguatan Riset dan Pengembangan, Kementerian Riset, Teknologi dan Pendidikan Tinggi.

Depdiknas. (2003). Undang-undang RI No.20 tahun 2003 tentang Sistem Pendidikan Nasional.

Elektrik Book

Dameze.blogspot.com/2011/05/makal ah-dampak - limbah - terhadap.html.

Kementerian Pendidikan dan Kebudayaan RI.

(2012). Dokumen Kurikulum 2013. Jakarta:

Kementerian Pendidikan dan Kebudayaan RI.

Rahmani, G.A. (2014). Lukisan Kaca Cermin Drupadi Dalam Pewayangan Epos. Mengajar. Jakarta: Grafindo.

Sutjipto, Katjik. (1973). Seni Rupa sebagai Alat Pendidikan, Sub Proyek Penulisan Buku Pelajaran. IKIP Malang. Malang:

Zakihasbi2 (2013). Seni Melukis di Atas Kaca.

[Online].https://alfhadl.wordpress.com/2013/ 02/26/seni-melukis-di-ataskacagelasbelingglass-painting/
Sardiman,A.M.2006. Interaksi dan Motivasi Belajar 